\title{
A Rational Pricing Explanation for the Failure of the CAPM
}

\author{
Hui Guo
}

F ama and French (2003), among many others, show that the capital asset pricing model (CAPM) does not explain stock returns. These results should not be a surprise because the model has some strong assumptions, and the failure of any one of them may cause the model to fail. In particular, the CAPM is a static model in which expected stock returns are assumed to be constant. However, if expected returns are time-varying, Merton (1973) and Campbell (1993), among others, show that the return on an asset is determined not only by its covariance with stock market returns, as in the CAPM, but also by its covariance with variables that forecast stock market returns. In this article, I estimate a variant of Campbell's intertemporal CAPM (ICAPM), using forecasting variables advocated in recent research. I find that the CAPM fails to explain the predictability of stock market returns because covariances with the forecasting variables are also important determinants of stock market returns. Therefore, consistent with some recent authors, for example, Brennan, Wang, and Xia (forthcoming) and Campbell and Vuolteenaho (2002), the failure of the CAPM is related to timevarying expected returns.

The remainder of the article is organized as follows. I first briefly summarize the recent developments of the asset pricing literature and then present evidence that stock market returns and volatility are predictable. For illustration, I discuss and estimate a variant of Campbell's ICAPM and show that changing investment opportunities have important effects on stock prices. ${ }^{1}$

\section{A BRIEF REVIEW OF THE LITERATURE}

In the past two decades, financial economists have documented many anomalies in financial

\footnotetext{
1 Stock market returns and volatility are measures of investment opportunities.
}

markets. For example, contrary to the market efficiency hypothesis by Fama (1970), Fama and French (1989) argue that stock market returns are predictable. There is also evidence of the predictability in the cross section of stock returns, which casts doubt on the widely accepted CAPM by Sharpe (1964) and Lintner (1965). In particular, Fama and French (1992, 1993) report that value stocks, stocks of high book-to-market value ratio, have much higher riskadjusted returns than growth stocks, stocks of low book-to-market value ratio. Also, Jegadeesh and Titman (1993) show that the momentum strategy of buying the past winners and selling the past losers is quite profitable.

The advocates of the market efficiency hypothesis argue quite convincingly that many of these anomalies can be attributed to data snooping. For example, if we experiment with a large number of macro variables, it should not be a surprise that a few of them might be correlated with future stock market returns by chance. However, investors cannot profit from such an ex post relation if it does not persist in the future. Indeed, Bossaerts and Hillion (1999), among others, find that, although the variables uncovered by the early authors forecast stock returns in sample, their out-of-sample predictive power is negligible. Similarly, Schwert (2002), among others, finds that many trading strategies, which have been found to generate abnormal returns, were unprofitable in the past decade. Overall, Malkiel (2003) asserts that there is no reliable evidence of persistent stock return predictability and the U.S. equity market is remarkably efficient in the sense that abnormal returns disappear quickly after they are discovered.

Some anomalies, however, cannot be easily discarded as data snooping. Jegadeesh and Titman (2001) and Schwert (2002) find that the momentum strategy remained highly profitable in the 1990s, one decade after it was published in academic jour-

Hui Guo is an economist at the Federal Reserve Bank of St. Louis. William Bock and Jason Higbee provided research assistance.

Federal Reserve Bank of St. Louis Review, May/June 2004, 86(3), pp. 23-33.

(C) 2004, The Federal Reserve Bank of St. Louis. 


\section{Table 1}

\section{Forecasting Quarterly Stock Market Returns and Volatility}

\begin{tabular}{|c|c|c|c|c|c|}
\hline Intercept & $r_{m}$ & cay & $\sigma_{m}^{2}$ & rrel & Adjusted $R^{2}$ \\
\hline \multicolumn{6}{|c|}{ Return } \\
\hline $\begin{array}{c}-1.50 \\
(-5.12)\end{array}$ & $\begin{array}{c}0.02 \\
(0.34)\end{array}$ & $\begin{array}{c}2.42 \\
(5.13)\end{array}$ & $\begin{array}{c}7.19 \\
(4.73)\end{array}$ & $\begin{array}{c}-5.63 \\
(-2.95)\end{array}$ & 0.20 \\
\hline \multicolumn{6}{|c|}{ Volatility } \\
\hline $\begin{array}{c}0.05 \\
(3.49)\end{array}$ & $\begin{array}{c}0.01 \\
(1.32)\end{array}$ & $\begin{array}{c}-0.09 \\
(-3.37)\end{array}$ & $\begin{array}{c}0.39 \\
(4.17)\end{array}$ & $\begin{array}{c}0.68 \\
(0.93)\end{array}$ & 0.24 \\
\hline
\end{tabular}

NOTE: White-corrected $t$-statistics are in parentheses.

nals. Also, recent authors, for example, Lettau and Ludvigson (2001), show that the consumption-wealth ratio, especially when combined with realized stock market volatility, has statistically and economically significant out-of-sample forecasting power for stock market returns. It is reasonable to believe, as argued by Campbell (2000), that stock returns have some predictable variations. Moreover, the excess stock volatility puzzle (Shiller, 1981), the equity premium puzzle (Mehra and Prescott, 1985), and large fluctuations of stock market volatility (Schwert, 1989) remain unexplained by conventional theories (e.g., Lucas, 1978).

The failure of rational expectations theories leads some researchers to be skeptical about the assumption that individual investors are fully rational. They try to incorporate various welldocumented cognitive biases into asset pricing models and find that such combinations have some success in explaining the anomalies mentioned above. Behavioral finance has developed rapidly since the 1990s, and Shiller (2003), among others, has stressed its important role in rebuilding modern finance. However, in my view, we should be at least cautious about it. The main criticism is that a long list of cognitive biases gives researchers so many degrees of freedom that anything can be explained. But financial economists are more interested in the out-of-sample forecast than in explaining what has happened. Also, it is difficult to believe that the investors who frequently misinterpret fundamentals can survive in an arbitrage-driven financial market. Barberis and Thaler (2003) provide a comprehensive survey of the behavioral finance literature and come to this conclusion: "First, we will find that most of our current theories, both rational and behavioral, are wrong. Second, substantially better theories will emerge."

In this article, I want to emphasize the promising role of another alternative hypothesis-stock return predictability does not necessarily contradict rational expectations theories. ${ }^{2}$ In particular, Campbell and Cochrane (1999) recently proposed a novel explanation using a habit-formation model that investors are more risk tolerant and thus require a smaller equity premium during economic expansions than during economic recessions. Their model not only replicates stock return predictability, but also resolves many other outstanding issues, including the equity premium puzzle and the excess volatility puzzle.

As mentioned, stock return predictability has important implications for asset pricing. Fama (1991) also conjectures that we should relate the crosssection properties of expected returns to the variation of expected returns through time. Consistent with these theories, some recent authors (e.g., Brennan, Wang, and Xia, forthcoming; and Campbell and Vuolteenaho, 2002) find that the predictability of stock market returns and volatility indeed helps explain the cross section of stock returns.

\section{FORECASTING STOCK MARKET RETURNS AND VOLATILITY}

The early authors, for example, Campbell (1987) and Fama and French (1989), find that the short-

\footnotetext{
2 This point has been well understood in theory; for example, Lucas (1978) shows that predictable variations of stock returns should be explained by predictable variations of consumption growth. Similarly, in the CAPM, the equity premium is predictable because of predictable variations of stock market volatility, a measure of stock market risk. However, these models cannot generate sizable predictable variations of stock returns as observed in the data.
} 


\section{Figure 1}

\section{Expected Excess Stock Market Returns}

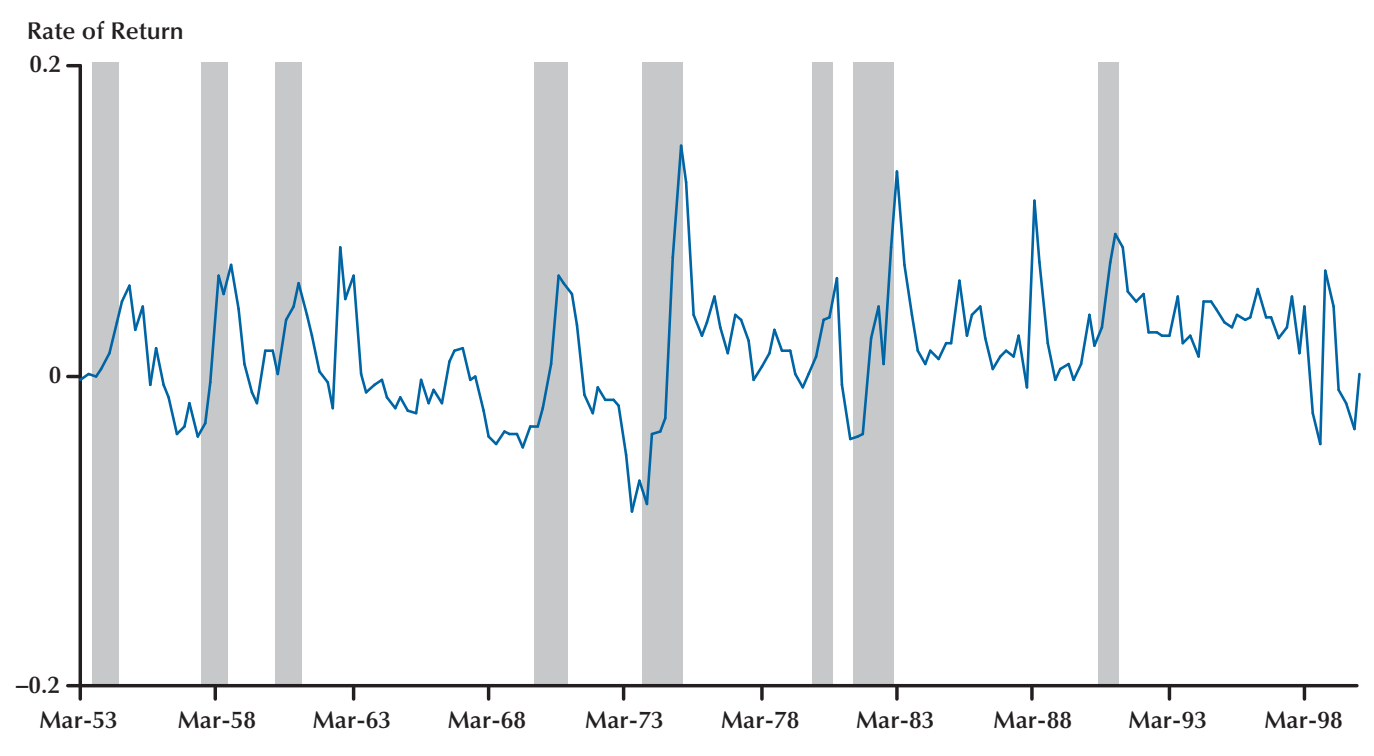

NOTE: Shaded bars indicate recessions as determined by the National Bureau of Economic Research.

term interest rate, the dividend yield, the default premium, and the term premium forecast stock market returns. Recently, Lettau and Ludvigson (2001) report that the consumption-wealth ratio, cay - the error term from the cointegration relation among consumption, net worth, and labor incomeforecasts stock market returns in sample and out of sample. Interestingly, I (Guo, 2003a) find that the predictive power of cay improves substantially if past stock market variance, $\sigma_{m}^{2}$, is also included in the forecasting equation and the stochastically detrended risk-free rate, $r r e l$, provides additional information about future returns. ${ }^{3}$

I replicate this result in the upper panel of Table 1, with the White-corrected (White, 1980) $t$ statistics reported in parentheses. It shows that all three variables are statistically significant in the forecasting equation of real stock market return, $r_{m}$, and the adjusted $R^{2}$ is about 20 percent; however, the lagged dependent variable is insignificant. 4 Moreover, these variables drive out the other commonly used forecasting variables, including the dividend yield, the default premium, and the term

\footnotetext{
3 The stochastically detrended risk-free rate is the difference between the nominal risk-free rate and its average in the previous 12 months.

4 See the appendix for data descriptions.
}

premium. ${ }^{5}$ Figure 1 plots the fitted value from the forecasting regression of returns and shows that expected returns tend to rise during recessions.

Schwert (1989), among many others, also finds clustering in stock market volatility: When volatility increases, it stays at its high level for an extended period before it reverts to its average level. Research shows that some macro variables predict stock volatility as well. Consistent with Lettau and Ludvigson (2003), the lower panel of Table 1 shows that, while past volatility is positively related to future volatility, cay is negatively related to it. Figure 2 plots the fitted value from the forecasting regression of stock market volatility, which also tends to increase during recessions.

I (Guo, 2003b) provide some theoretical insight on these empirical results in a limited stock market participation model. In particular, I argue that, in addition to a market risk premium (as in the standard consumption-based model), investors also require a liquidity premium on stocks because investors cannot use stocks to hedge income risk-due to limited stock market participation. Therefore, stock volatility and the consumption-wealth ratio forecast

5 To conserve space, I do not report the results here; but they are available upon request. 
Expected Stock Market Volatility

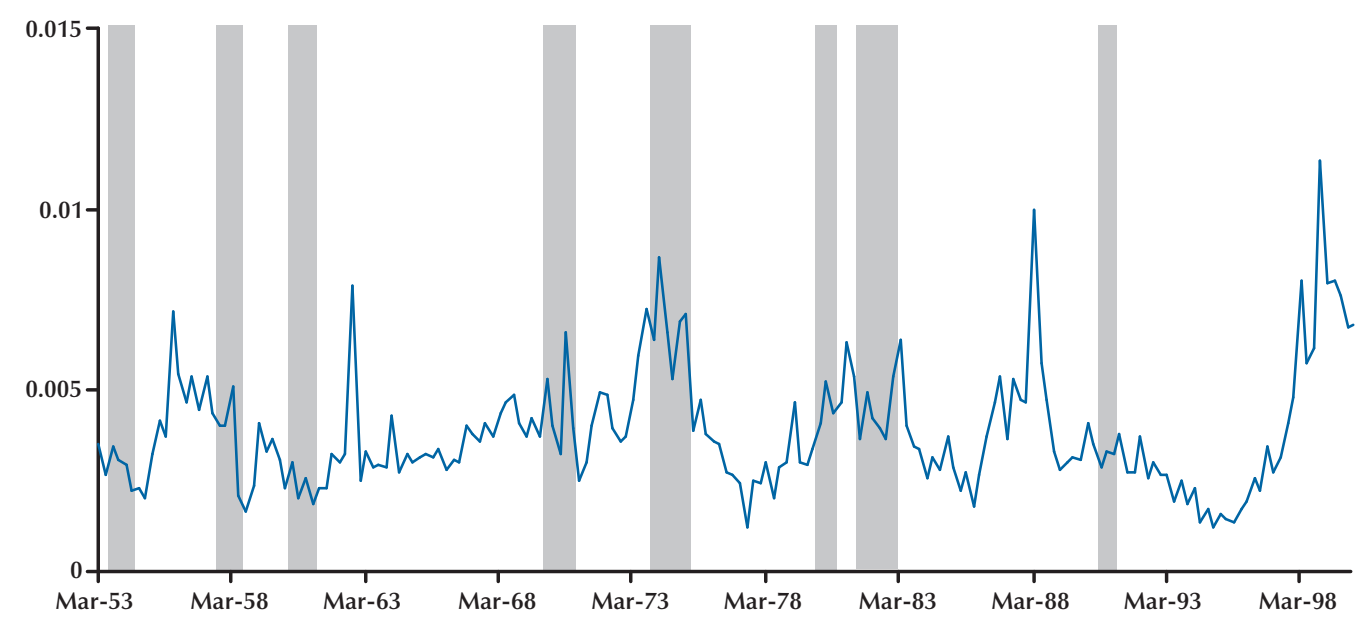

NOTE: Shaded bars indicate recessions as determined by the National Bureau of Economic Research.

stock market returns because they are proxies for the risk and liquidity premiums, respectively. ${ }^{6}$

It should not be a surprise that stock market volatility forecasts returns, which is an important implication of the CAPM. ${ }^{7}$ Intuitively, risk-averse investors tend to reduce their holding of equities relative to safe assets such as Treasury bills when volatility is expected to rise. To induce investors to hold a broadly measured stock market index, the expected stock market return has to rise as well. Given that the level of volatility tends to persist over time, we expect that past volatility should provide some indication of future volatility and hence stock market returns. On the other hand, the consumption-wealth ratio measures investors' liquidity conditions. When investors are borrowing constrained because of, for example, a bad income shock, they require a high liquidity premium on stocks and stock prices thus fall. Conversely, the liquidity premium is low and stock prices rise when investors have plenty of liquidity.

6 Patelis (1997) suggests that variables such as the stochastically detrended risk-free rate forecast stock returns because these variables reflect the stance of monetary policies, which have state-dependent effects on real economic activities through a credit channel (e.g., Bernanke and Gertler, 1989).

7

However, it is puzzling that many authors (e.g., Campbell, 1987; Glosten, Jagannathan, and Runkle, 1993; and Lettau and Ludvigson, 2003) report a negative risk-return tradeoff in the stock market. As I will discuss here, these results reflect the fact that the early authors fail to control for the liquidity premium, which may be negatively related to the risk premium.
It is important to note that the risk and liquidity premiums or their proxies, stock market volatility and the consumption-wealth ratio, could be negatively related to one another in the limited stock market participation model. Intuitively, when investors have excess liquidity, they might be willing to hold stocks when the expected return is low, even though expected volatility is high. This implication is particularly relevant for the stock market boom in the late 1990s, during which investors accepted a low expected return even though volatility rose to a historically high level. Indeed, as shown in Table 1, while volatility and the consumption-wealth ratio are both positively related to future stock market returns, they are negatively related to one another in the post-World War II sample. This pattern explains that, because of an omitted variable problem, the predictive power of the consumption-wealth ratio improves dramatically when past variance is also included in the forecast equation. As shown in Guo and Whitelaw (2003), it also explains why the early authors fail to find conclusive evidence of a positive risk-return relation, as stipulated by the CAPM.

There is an important conceptual issue of using the consumption-wealth ratio as a forecasting variable, because consumption and labor income data are subject to revision. In particular, Guo (2003c) finds that the predictive power of the consumptionwealth ratio deteriorates substantially if we use information available at the time of the forecast. It is 
important to note that the use of real-time data does not call the predictive abilities of the consumptionwealth ratio into question. In fact, we expect the consumption-wealth ratio to have better predictive power in the current vintage data than in the realtime data because the latter is a noisier and potentially biased measure of its "true" value. Moreover, investors may obtain similar information from alternative sources; for example, Guo and Savickas (2003a) show that a measure of the (value-weighted) idiosyncratic volatility, which is available in real time, has forecasting abilities that are very similar to those of the consumption-wealth ratio. Therefore, as stressed by Lettau and Ludvigson (2003), it is appropriate to use the consumption-wealth ratio estimated from the current vintage data in this paper because I address the question of whether expected excess returns are time-varying. ${ }^{8}$

\section{CAMPBELL'S ICAPM}

In this section, I briefly discuss how stock market returns are determined in a rational expectations model (i.e., Campbell's, 1993, ICAPM) if stock market returns and volatility are predictable. In particular, Campbell argues that the expected return on any asset is determined by its covariance with stock market returns and variables that forecast stock market returns. This simple exercise helps illustrate why the CAPM fails to explain the cross section of stock returns, as mentioned in the introduction.

Campbell's ICAPM is quite intuitive. For example, because the consumption-wealth ratio is positively related to future stock market returns, a negative innovation in the consumption-wealth ratio indicates a low future expected return or worsened "future investment opportunities." A stock is thus risky if its return is low when future investment opportunities deteriorate-that is, there is a negative shock to the consumption-wealth ratio. As a result, in addition to compensation for the market risk, investors require additional compensation on this stock because it provides a poor hedge for changing investment opportunities. Below, I briefly discuss the testable implications of Campbell's ICAPM. Interested readers may look to Campbell (1993, 1996) for details.

\footnotetext{
8 I focus on the consumption-wealth ratio in this article because, as mentioned, it is a theoretically motivated variable. In contrast, the idiosyncratic volatility forecasts stock returns because of its comovements with the consumption-wealth ratio, and such a link has not been well understood. Also, the consumption-wealth ratio is available in a longer sample than the idiosyncratic volatility.
}

Campbell's ICAPM is a model of an infinite horizon economy, in which a representative agent maximizes an Epstein and Zin (1989) objective function,

(1)

$$
\begin{aligned}
U_{t} & =\left\{(1-\beta\} C_{t}^{1-(1 / \sigma)}+\beta\left(E_{t} U_{t+1}^{1-\gamma}\right)^{[1-(1 / \sigma)] /(1-\gamma)}\right\}^{1 /[1-(1 / \sigma)]} \\
& =\left[(1-\beta) C_{t}^{(1-\gamma) / \theta}+\beta\left(E_{t} U_{t+1}^{1-\gamma}\right)^{1 / \theta}\right]^{\theta /(1-\gamma)},
\end{aligned}
$$

subject to the intertemporal budget constraint

$$
W_{t+1}=R_{m, t+1}\left(W_{t}-C_{t}\right) \text {. }
$$

In the above equations, $C_{t}$ is consumption, $W_{t}$ is aggregate wealth, $R_{m, t+1}$ is the return on aggregate wealth, $\beta$ is the time discount factor, $\gamma$ is the relative risk aversion coefficient, $\sigma$ is the elasticity of intertemporal substitution, and $\theta$ is defined as $\theta=(1-\gamma) /$ $[1-(1 / \sigma)]$. If we set $\theta$ equal to 1 , we obtain the familiar power utility function, in which the relative risk aversion coefficient is equal to the reciprocal of the elasticity of intertemporal substitution.

Suppose that there are $(K-1)$ state variables, $x_{t+1}=\left[x_{1, t+1}, \ldots, x_{K-1, t+1}\right]^{\prime}$, lags of which forecast stock market return, $r_{m, t+1}$, and its volatility. ${ }^{9}$ Also, $r_{m, t+1}$ and $x_{t+1}$ follow a first-order vector autoregressive (VAR) process:

$$
\left[\begin{array}{c}
r_{m, t+1} \\
x_{t+1}
\end{array}\right]-A_{0}-A\left[\begin{array}{c}
r_{m, t} \\
x_{t}
\end{array}\right]=\left[\begin{array}{c}
\varepsilon_{1, t+1} \\
\vdots \\
\varepsilon_{K, t+1}
\end{array}\right],
$$

where $A_{0}$ is a $K$-by- 1 vector of intercepts, $A$ is a $K$-by- $K$ matrix of slope coefficients, and $\left[\varepsilon_{1, t+1}, \varepsilon_{2, t+1}, \ldots\right.$, $\left.\varepsilon_{K, t+1}\right]^{\prime}$ is a $K$-by- 1 vector of error terms, which are orthogonal to the lagged state variables. Campbell (1993) shows that, if stock market returns and volatility are predictable, as shown in equation (3), the expected return on any asset, e.g., $r_{i, t+1}$, is determined by its covariance with stock market returns and variables that forecast stock market returns:

$$
E_{t} r_{i, t+1}-r_{f, t+1}+\frac{V_{i i, t}}{2}=\gamma V_{i m, t}+\sum_{k=1}^{K}\left[\left(\gamma-1-\frac{\theta \psi}{\sigma}\right)\right] \lambda_{h k} V_{i k, t},
$$

where $r_{f, t+1}$ is the risk-free rate, $V$ is conditional variance or covariance, $\Psi$ is the coefficient relating stock market return to volatility, and $\lambda_{h k}$ is a function

\footnotetext{
$9 r_{m, t+1}$ is the log of return on aggregate wealth, $R_{m, t+1}$.
} 
Table 2

\section{Model Specifications}

\begin{tabular}{ll} 
Model & \multicolumn{1}{c}{ Restrictions on equation (5) } \\
\hline I & $\lambda_{h k}=0, k=1, \ldots, K$ \\
II & $\frac{\theta \psi}{\sigma}=0$ \\
III & No restrictions \\
IV & Coefficients of $\varepsilon_{m, t+1} \varepsilon_{k, t+1}, k=1, \ldots, K$ \\
& are free parameters \\
\hline
\end{tabular}

of $A .{ }^{10}$ In particular, excess stock market return is given by

$$
\begin{aligned}
& r_{m, t+1}-r_{f, t+1}+\frac{\varepsilon^{2} m, t+1}{2}-\gamma \varepsilon_{m, t+1}^{2} \\
& -\sum_{k=1}^{K}\left[\left(\gamma-1-\frac{\theta \psi}{\sigma}\right)\right] \lambda_{h k} \varepsilon_{m, t+1} \varepsilon_{k, t+1}=u_{m, t+1},
\end{aligned}
$$

where $\varepsilon_{m, t+1}$ is the shock to the stock market return, which I also denote as $\varepsilon_{1, t+1}$ in equation (3). Equation (5) indicates that stock market return is predictable because its covariances with state variables - for example, stock market volatility, $\varepsilon_{m, t+1}^{2}-$ are predictable.

Campbell's ICAPM of equations (3) and (5) can be estimated using the generalized method of moments (GMM) by Hansen (1982). I use a quarterly sample spanning from 1952:Q4 to 2000:Q4, with a total of 193 observations. To mitigate the potential small sample problem, I follow the advice of Ferson and Foerster (1994) and use the iterative GMM unless otherwise noted. I assume that the error terms in equations (3) and (5) are orthogonal to the lagged state variables and have zero means. Equation (3) is exactly identified. In equation (5), there are two parameters, $\gamma$ and $\frac{\theta \psi}{\sigma}$, and $K+1$ orthogonality conditions. The equation system, therefore, is overidentified with $K-1$ degrees of freedom. Hansen's (1982) $\mathrm{J}$-test can be used to test the null hypothesis that the pricing error of equation (5), $u_{m, t+1}$, is orthogonal to the lagged state variables and has a zero mean. We can also back-out the price of risk for each factor using the formula

10 For example, $V_{i 1, t}=E_{t}\left(\varepsilon_{1, t+1} \varepsilon_{i, t+1}\right)$ is the conditional covariance between the shock to stock market return, $\varepsilon_{1, t+1}$, and the shock to the return on asset $i, \varepsilon_{i, t+1}$. To derive equation (4), I also use a simplifying assumption, $E_{t} r_{m, t+1}=\Psi V_{m m, t}$, as suggested by Campbell (1993).
(6)

$$
\begin{aligned}
& p_{1}=\gamma+\left[\left(\gamma-1-\frac{\theta \psi}{\sigma}\right)\right] \lambda_{h 1} \\
& p_{i}=\left[\left(\gamma-1-\frac{\theta \psi}{\sigma}\right)\right] \lambda_{h i}, i=2, \ldots, K,
\end{aligned}
$$

where $p_{1}$ is the risk price for stock market returns and $p_{i}$ is the risk price for forecasting variable $i$.

If we impose the restriction that $\Psi$-the parameter for time-varying stock market volatility - is equal to zero, we obtain the special case analyzed by Campbell (1996), in which volatility changes have no effects on asset prices. It should be noted that, as discussed in footnote 10 , equation (4) or (5) is a special case of Campbell's ICAPM with time-varying volatility. Under general conditions (e.g., conditional stock market volatility is a linear function of lagged state variables), I (Guo, 2002) show that conditional stock market return is still a linear function of its covariances with state variables, but the risk prices are complicated functions of the underlying structural parameters. For robustness, I also estimate equation (5) by assuming that the risk prices are free parameters. It should also be noted that equation (5) reduces to the familiar CAPM if we drop the covariances between stock market returns and the forecasting variables. These four specifications are nested, and the $D$-test proposed by Newey and West (1987) can be used to test the restrictions across these specifications.

Table 2 summarizes the specifications of the four models investigated in this paper. Model I is the CAPM, in which I assume that the covariances with variables that forecast stock market returns have no effects on the expected stock market return. Model II is Campbell's ICAPM with constant stock market volatility, in which the parameter $\frac{\theta \psi}{\sigma}$ is restricted to be zero. In Model III, I allow volatility changes to affect the expected stock market return and estimate $\frac{\theta \psi}{\sigma}$ as a free parameter. Model IV is the general case of Campbell's ICAPM, in which I estimate the risk prices as free parameters. In models II and III, I estimate the structural parameters $\gamma$ and/or $\frac{\theta \psi}{\sigma}$ and use equation (6) to back-out the risk prices. The risk prices are estimated directly in models I and IV.

\section{EMPIRICAL RESULTS}

Before presenting the empirical results, I want to emphasize that Campbell's ICAPM is not a general 


\section{Table 3}

\section{Campbell's ICAPM with Constant $\gamma$}

\begin{tabular}{|c|c|c|c|c|c|c|c|}
\hline \multirow[b]{2}{*}{ Model } & \multirow[b]{2}{*}{$\gamma$} & \multirow[b]{2}{*}{$\frac{\theta \psi}{\sigma}$} & \multicolumn{4}{|c|}{ Risk prices for } & \multirow[b]{2}{*}{$J$-test ( $p$-value $)$} \\
\hline & & & $r_{m}$ & cay & $\sigma_{m}^{2}$ & rrel & \\
\hline I & $\begin{array}{c}6.53 \\
(5.12)\end{array}$ & & $\begin{array}{c}6.53 \\
(5.12)\end{array}$ & & & & $\begin{array}{c}\chi^{2}(4)=14.01 \\
(0.01)\end{array}$ \\
\hline II* & $\begin{array}{c}32.82 \\
(3.35)\end{array}$ & & $\begin{array}{c}9.50 \\
(3.13)\end{array}$ & $\begin{array}{r}441.67 \\
(2.79)\end{array}$ & $\begin{array}{r}405.79 \\
(3.37)\end{array}$ & $\begin{array}{r}-807.87 \\
(-3.17)\end{array}$ & $\begin{array}{c}\chi^{2}(4)=7.12 \\
(0.13)\end{array}$ \\
\hline III & $\begin{array}{l}31.29 \\
(2.31)\end{array}$ & $\begin{array}{l}-14.62 \\
(-1.97)\end{array}$ & $\begin{array}{c}8.91 \\
(2.02)\end{array}$ & $\begin{array}{r}449.16 \\
(2.10)\end{array}$ & $\begin{array}{r}447.76 \\
(2.40)\end{array}$ & $\begin{array}{r}-719.24 \\
(-2.58)\end{array}$ & $\begin{array}{c}\chi^{2}(3)=0.73 \\
(0.87)\end{array}$ \\
\hline IV & & & $\begin{array}{c}9.32 \\
(1.03)\end{array}$ & $\begin{array}{c}71.44 \\
(0.18)\end{array}$ & $\begin{array}{r}387.39 \\
(1.27)\end{array}$ & $\begin{array}{r}-739.37 \\
(-0.94)\end{array}$ & $\begin{array}{c}\chi^{2}(1)=0.04 \\
(0.85)\end{array}$ \\
\hline
\end{tabular}

D-test (p-value)

I vs. IV: $\chi^{2}(3)=19.64(0.00)$
II vs. IV: $\chi^{2}(3)=7.19(0.07)$
II vs. III: $\chi^{2}(1)=5.60(0.02)$
III vs. IV: $\chi^{2}(2)=1.01(0.60)$

NOTE: * I use the identity matrix as the initial weighting matrix and use five iterations; $t$-statistics are in parentheses unless otherwise indicated.

equilibrium model, because it takes stock return predictability as given. Therefore, the test of Campbell's ICAPM is a joint test of an equilibrium model, which explains the choice of forecasting variables. This explains, in contrast with my results, that the early authors such as Campbell (1996), Li (1997), and Chen (2002) find little support for Campbell's ICAPM because they use different sets of forecasting variables.

Table 3 presents the empirical results. Consistent with asset pricing theories, the relative risk aversion coefficient, $\gamma$, is statistically positive with a point estimate of about 6.5 in model I. ${ }^{11}$ However, the $J$ test rejects the model at the 1 percent significance level, indicating that the stock return predictability cannot be explained solely by predictable variations in volatility. This result, which is consistent with Harvey (1989), should not be a surprise. Table 1 shows that other variables such as the consumptionwealth ratio and the stochastically detrended riskfree rate also forecast stock market returns. Their covariances with stock market returns, therefore,

${ }^{11}$ The price of the market risk is equal to the relative risk aversion coefficient in the CAPM. are also components of the expected stock market return, as shown in equation (5).

In model II, the relative risk aversion coefficient is also significantly positive, with a point estimate of about 32.8. Moreover, the risk prices of all factors are statistically significant with expected signs. In particular, the covariance with the consumptionwealth ratio, cay, and realized stock market variance, $\sigma_{m}^{2}$, is positively priced because these two variables are positively related to future stock market returns, as shown in Table 1. Similarly, the covariance with the stochastically detrended risk-free rate, $r r e l$, is negatively priced because it is negatively related to future stock market returns. The price of the market risk, $r_{m}$, is positive; its point estimate of 9.5 , however, is much smaller than that of the relative risk aversion coefficient. This result, as argued by Campbell (1996), reflects the mean-reversion in stock market returns. However, there is only weak support for model II: It is not rejected at the 10 percent significance level by the $J$-test.

In model III, the coefficient $\frac{\theta \psi}{\sigma}$ is negative and statistically significant. This should not be a surprise given mounting evidence of large fluctuations in 


\section{A Decomposition of Stock Market Return}

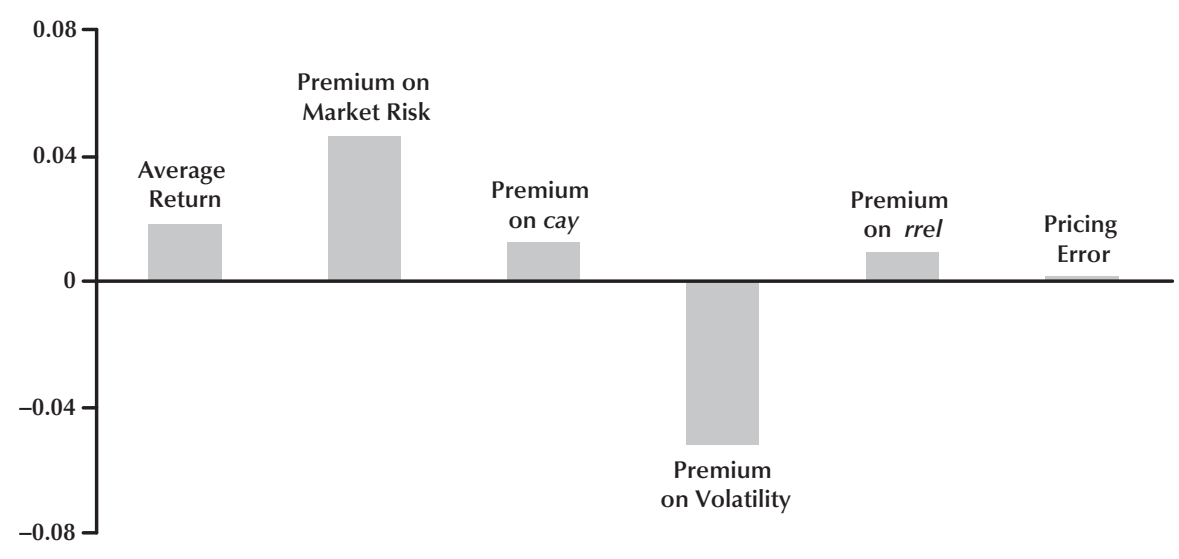

stock market volatility, e.g., Schwert (1989). Moreover, model III fits the data pretty well: It is not rejected at the 80 percent significance level, according to the $J$-test. Nevertheless, the point estimates of the relative risk aversion coefficient and the risk prices are similar to those reported in model II. Finally, we find that model IV, the most general specification, also explains the dynamic of stock market returns well.

The $D$-test reveals a similar pattern. Model I is overwhelmingly rejected relative to model IV, indicating that the CAPM cannot explain the dynamic of stock market returns. Model II is also rejected relative to models III and IV, indicating that changes in volatility have important effects on asset prices. ${ }^{12}$ However, we cannot reject model III relative to model IV at the 60 percent significance level. Therefore, equation (4) or (5) provides a good approximation for the effect of return heteroskedasticity. One advantage of model III is that it allows us to estimate the structural parameter of the relative risk aversion coefficient, $\gamma$.

In Figure 3, I use the estimation results of model III in Table 2 to decompose the average stock market return into its covariances with the four risk factors and the pricing error. It shows that, although the market risk is an important determinant of the average return, the risk premiums on cay, $\sigma_{m}^{2}$, and rrel are also substantial. The pricing error, however, is very small relative to the average return, which confirms the $J$-test in Table 3.

12 Ang et al. (2003) also find that stock market volatility is a significantly priced risk factor.
Figure 3 sheds light on the failure of the CAPM, as argued by Fama and French (2003), among others: The market risk is not the only determinant of stock returns when conditional stock market return and volatility change over time. For example, as mentioned in the introduction, value stocks earn higher average returns than growth stocks, even though their covariances with stock market returns are similar. This is because value stocks have higher covariances with cay than growth stocks; similarly, the momentum profit is explained by the fact that the past winners have higher covariances with $\sigma_{m}^{2}$ than the past losers do (Guo, 2002). Brennan, Wang, and Xia (forthcoming) and Campbell and Vuolteenaho (2002) also find that a hedge for changing investment opportunities explains the value premium, although they use different instrumental variables.

Lastly, I want to stress that, although many financial economists agree that the CAPM does not explain the cross section of stock returns, they disagree on the source of the deviation from the CAPM. This is because the early authors test the CAPM using portfolios formed according to various characteristics, such as book-to-market value ratios, and the failure of the CAPM is consistent with a host of alternative hypotheses. For example, while Fama and French (2003) interpret the value premium as being consistent with ICAPM, Lakonishok, Shleifer, and Vishny (1994) and Mackinlay (1995) attribute it to irrational pricing and data mining. ${ }^{13}$ Based on

\footnotetext{
13 The value premium is the return on a portfolio that is long in stocks with high book-to-market value ratios and short in stocks with low book-to-market value ratios.
} 
Campbell's ICAPM or equation (4), Guo and Savickas (2003b) provide some new insight on this issue by forming portfolios on conditionally expected returns. In particular, they use the same variables used in this paper to make out-of-sample forecasts for individual stocks and then sort the stocks into decile portfolios based on the forecast. They show that the decile portfolios, which are motivated directly from the ICAPM and thus not vulnerable to the criticism of data mining or irrational pricing, pose a serious challenge to the CAPM. Their results provide direct support for ICAPM.

\section{CONCLUSION}

In this article, I provide a brief survey of rational pricing explanations for stock return predictability. For illustration purposes, I also estimate and test a variant of Campbell's ICAPM, which allows for timevarying conditional return and volatility. Consistent with the recent authors, ICAPM appears to explain the dynamic of stock market returns better than the CAPM does. The results suggest that stock return predictability is important for understanding asset pricing.

\section{REFERENCES}

Ang, Andrew; Hodrick, Robert J.; Xing, Yuhang and Zhang, Xiaoyan. "The Cross-Section of Volatility and Expected Returns.” Working paper, Columbia Business School, 2003.

Barberis, Nicholas C. and Thaler, Robert H. "A Survey of Behavioral Finance," in George Constantinides, Milton Harris, Rene Stulz, eds., Handbook of the Economics of Finance. Amsterdam: North-Holland, 2003.

Bernanke, Ben S. and Gertler, Mark. "Agency Costs, Net Worth, and Business Fluctuations." American Economic Review, March 1989, 79(1), pp. 14-31.

Bossaerts, Peter and Hillion, Pierre. "Implementing Statistical Criteria to Select Return Forecasting Models: What Do We Learn?" Review of Financial Studies, Summer 1999, 12(2), pp. 405-28.

Brennan, Michael J.; Wang, Ashley W. and Xia, Yihong. "Estimation and Test of a Simple Model of Intertemporal Capital Asset Pricing” (forthcoming in Journal of Finance).

Campbell, John Y. "Stock Returns and the Term Structure." Journal of Financial Economics, June 1987, 18(2), pp. 373-99.
Campbell, John Y. "Intertemporal Asset Pricing without Consumption Data." American Economic Review, June 1993, 83(3), pp. 487-512.

Campbell, John Y. "Understanding Risk and Return." Journal of Political Economy, April 1996, 104(2), pp. 298-345.

Campbell, John Y. "Asset Pricing at the Millennium." Journal of Finance, August 2000, 55(4), pp. 1515-67.

Campbell, John Y. and Cochrane, John H. "By Force of Habit: A Consumption-Based Explanation of Aggregate Stock Market Behavior." Journal of Political Economy, April 1999, 107(2), pp. 205-51.

Campbell, John Y.; Lettau, Martin; Malkiel, Burton G. and $\mathrm{Xu}$, Yexiao. "Have Individual Stocks Become More Volatile? An Empirical Exploration of Idiosyncratic Risk.” Journal of Finance, February 2001, 56(1), pp. 1-43.

Campbell, John Y. and Vuolteenaho, Tuomo. "Bad Beta, Good Beta.” Working paper, Harvard University, 2002.

Chen, Joseph. "Intertemporal CAPM and the Cross-Section of Stock Returns.” Working paper, University of Southern California, 2002.

Epstein, Larry G. and Zin, Stanley E. "Substitution, Risk Aversion, and the Temporal Behavior of Asset Returns." Journal of Political Economy, April 1989, 99(2), pp. 263-86.

Fama, Eugene. "Efficient Capital Markets: A Review of Theory and Empirical Work." Journal of Finance, May 1970, 25(2), pp. 383-417.

Fama, Eugene. "Efficient Capital Markets: II." Journal of Finance, December 1991, 46(5), pp. 1575-618.

Fama, Eugene and French, Kenneth. "Business Conditions and Expected Returns on Stocks and Bonds." Journal of Financial Economics, November 1989, 25(1), pp. 23-49.

Fama, Eugene and French, Kenneth. "The Cross-Section of Expected Stock Returns.” Journal of Finance, June 1992, 47(2), pp. 427-65.

Fama, Eugene and French, Kenneth. "Common Risk Factors in the Returns on Stocks and Bonds." Journal of Financial Economics, February 1993, 33(1), pp. 3-56.

Fama, Eugene and French, Kenneth. "The CAPM: Theory and Evidence." Working Paper No. 550, Center for Research in Security Prices, University of Chicago, 2003. 
Ferson, Wayne E. and Foerster, Stephen R. "Finite Sample Properties of the Generalized Method of Moments in Tests of Conditional Asset Pricing Models." Journal of Financial Economics, August 1994, 36(1), pp. 29-55.

Guo, Hui. "Time-Varying Risk Premia and the Cross Section of Stock Returns.” Working Paper 2002-013B, Federal Reserve Bank of St. Louis, 2002.

Guo, Hui. "On the Out-of-Sample Predictability of Stock Market Returns" (forthcoming in Journal of Business, 2003a).

Guo, Hui. "Limited Stock Market Participation and Asset Prices in a Dynamic Economy" (forthcoming in Journal of Financial and Quantitative Analysis, 2003b).

Guo, Hui. "On the Real-Time Forecasting Ability of the Consumption-Wealth Ratio.” Working Paper 2003-007b, Federal Reserve Bank of St. Louis, 2003c.

Guo, Hui and Savickas, Robert. "Idiosyncratic Volatility, Stock Market Volatility, and Expected Stock Returns." Working Paper 2003-028A, Federal Reverse Bank of St. Louis, 2003a.

Guo, Hui and Savickas, Robert. "On the Cross Section of Conditionally Expected Stock Returns.” Working Paper 2003-043A, Federal Reserve Bank of St. Louis, 2003b.

Guo, Hui and Whitelaw, Robert. "Uncovering the Risk-Return Relation in the Stock Market." NBER Working Paper 9927, National Bureau of Economic Research, 2003.

Glosten, Lawrence R.; Jagannathan, Ravi and Runkle, David E. "On the Relation Between the Expected Value and the Variance of the Nominal Excess Return on Stocks." Journal of Finance, December 1993, 48(5), pp. 1779-801.

Hansen, Lars P. "Large Sample Properties of Generalized Method of Moments Estimators.” Econometrica, July 1982, 50(4), pp. 1029-54.

Harvey, Campbell R. "Time-Varying Conditional Covariances in Tests of Asset Pricing Models.” Journal of Financial Economics, October 1989, 24(2), pp. 289-317.

Jegadeesh, Narasimhan and Titman, Sheridan. "Returns to Buying Winners and Selling Losers: Implications for Stock Market Efficiency." Journal of Finance, March 1993, 48(1), pp. 65-91.
Jegadeesh, Narasimhan and Titman, Sheridan. "Profitability of Momentum Strategies: An Evaluation of Alternative Explanations." Journal of Finance, April 2001, 56(2), pp. 699-720.

Lakonishok, Josef; Shleifer, Andrei and Vishny, Robert W. “Contrarian Investment, Extrapolation, and Risk." Journal of Finance, December 1994, 49(5), pp. 1541-78.

Lettau, Martin and Ludvigson, Sydney. "Consumption, Aggregate Wealth, and Expected Stock Returns." Journal of Finance, June 2001, 56(3), pp. 815-49.

Lettau, Martin and Ludvigson, Sydney. "Measuring and Modeling Variation in the Risk-Return Tradeoff." Working paper, New York University, 2003.

Li, Yuming. "Intertemporal Asset Pricing without Consumption Data: Empirical Tests." Journal of Financial Research, Spring 1997, 20(1), pp. 53-69.

Lintner, John. "Security Prices, Risk and Maximal Gains from Diversification." Journal of Finance, December 1965, 20(4), pp. 587-615.

Lucas, Robert E. Jr. "Asset Prices in an Exchange Economy." Econometrica, November 1978, 46(6), pp. 1429-46.

MacKinlay, Craig A. "Multifactor Models Do Not Explain Deviations from the CAPM." Journal of Financial Economics, May 1995, 38(1), pp. 3-28.

Malkiel, Burton G. "The Efficient Market Hypothesis and Its Critics." Journal of Economic Perspectives, Winter 2003, 17(1), pp. 59-82.

Mehra, Rjnish and Prescott, Edward C. "The Equity Premium: A Puzzle.” Journal of Monetary Economics, March 1985, 15(2), pp. 145-61.

Merton, Robert C. "An Intertemporal Capital Asset Pricing Model.” Econometrica, September 1973, 41(5), pp. 867-87.

Merton, Robert C. "On Estimating the Expected Return on the Market: An Exploratory Investigation.” Journal of Financial Economics, December 1980, 8(4), pp. 323-61.

Newey, Whitney K. and West, Kenneth D. "Hypothesis Testing with Efficient Method of Moments Estimation.” International Economic Review, October 1987, 28(3), pp. 777-87. 
Patelis, Alex D. "Stock Return Predictability and The Role of Monetary Policy." Journal of Finance, December 1997, 52(5), pp. 1951-72.

Schwert, William G. "Why Does Stock Market Volatility Change Over Time?" Journal of Finance, December 1989, 44(3), pp. 1115-53.

Schwert, William G. "Anomalies and Market Efficiency." Handbook of the Economics of Finance, Chap. 15. Amsterdam: North-Holland, 2002.

Sharpe, William F. "Capital Asset Prices: A Theory of Market Equilibrium Under Conditions of Risk." Journal of Finance, September 1964, 19(3), pp. 425-42.
Shiller, Robert J. "Do Stock Prices Move Too Much to Be Justified by Subsequent Changes in Dividends?" American Economic Review, June 1981, 71(3), pp. 421-36.

Shiller, Robert J. "From Efficient Markets Theory to Behavioral Finance." Journal of Economic Perspectives, Winter 2003, 17(1), pp. 83-104.

White, Halbert L. "A Heteroskedasticity-Consistent Covariance Matrix Estimator and a Direct Test for Heteroskedasticity." Econometrica, May 1980, 48(4), pp. 817-38.

\section{Appendix}

\section{DATA DESCRIPTIONS}

Because the consumption-wealth ratio, cay, is available on a quarterly basis, I analyze a quarterly sample spanning from 1952:Q4 to 2000:Q4, with a total of 193 observations. Following Merton (1980), among many others, realized stock market variance, $\sigma_{m}^{2}$, is the sum of the squared deviation of the daily excess stock return from its quarterly average in a given quarter. It should be noted that, as in Campbell et al. (2001), I make a downward adjustment for the realized stock market variance of $1987: \mathrm{Q} 4$, on which the 1987 stock market crash has a compounding effect. The stochastically detrended risk-free rate, $\mathrm{rrel}$, is the difference between the risk-free rate and its average over the previous four quarters, and the quarterly risk-free rate is approximated by the sum of the monthly risk-free rate in a quarter. The consumption-wealth ratio data were obtained from Martin Lettau at New York University. I obtain the daily value-weighted stock market return from the Center for Research in Security Prices (CRSP) at the University of Chicago. The daily risk-free rate is not directly available, but I assume that it is constant within a given month. The monthly risk-free rate is also obtained from the CRSP. The real stock market return, $r_{m}$, is the difference between the CRSP valueweighted market return and the inflation rate of the consumer price index obtained from the Bureau of Economic Analysis. 
RE V I E W 